\title{
Social Networks and the Live Reef Food Fish Trade: Examining Sustainability
}

\author{
Irendra Radjawali \\ Leibniz Center for Tropical Marine Ecology GmbH, Bremen
}

\section{Introduction}

The primary threat to nature and people today comes from centralising and monopolising power and control. Not until diversity is made the logic of production will there be a chance for sustainability, justice and peace. Cultivating and conserving diversity is no luxury in our times: it is a survival imperative.

Vandana Shiva

The term 'live reef food fish' (LRFF) refers to fish that are kept alive to preserve freshness until they can be cooked. Live reef food fishing is one of the important industries that provide incomes for many coastal and small-island communities. Johannes and Riepen (1995) estimated that Indonesia supplied half the market demand for live reef food fish for Singapore and Hong Kong, and Cesar (1996) estimated that the export of LRFF from Indonesia is between 10,000 and 20,000 tonnes per year (Bentley, 1997). One of the primary centres of the LRFF trade is the Spermonde Archipelago, South Sulawesi Province, Indonesia.

Different techniques and tools are used in live reef food fish fishing. Long-line fishing was the favoured method used by the fishermen during the beginning period of the industry in the Spermonde Archipelago in the mid-1980s, despite this method's relatively low catch rate. Some fishermen used a baited fish trap made from bamboo called a $b u b u$, 
which had a better catch rate. As well, many of them started to use cyanide to stun the fish, a technique that became popular because it increased their catch, despite the use of cyanide being illegal and it being a threat to the ecosystem.

On one hand, using cyanide increases the size of a fisherman's catch and consequent income, especially at times when there is a high demand from Hong Kong for fish, for example, when the Chinese New Year is celebrated. On the other hand, using cyanide has been reported to be threatening the ecosystem because it has led to overfishing. Overfishing, and the destruction of reefs, has led to declines in the populations of particular species of fish (Pet-Soede and Erdmann, 1998; Mous et al., 2000) and in the medium and long run this threatens the economic wellbeing of these fishing communities. Several species of LRFF that are caught for the commercial trade are on the Red List of the International Union for Conservation of Nature (IUCN). ${ }^{1}$ On the IUCN's list, for example, are Humphead Wrasse, which is categorised as endangered; Spotted Coral Trout as vulnerable; Leopard Coral Trout as near threatened; and High-finned Grouper as vulnerable. Clearly, the threat of overfishing is present.

Studies of the effect on reef ecosystems of the use of cyanide in fishing have been carried out and reported by many researchers. Mous and colleagues (Mous et al., 2006 ) reported that the effect of cyanide fishing on the coral cover is not as threatening as usually assumed, compared with the deleterious effects from the use of explosives for fishing and with the bleaching of coral caused by global climate change. However, the depletion of fish stocks because of excessive exploitation resulting from the use of cyanide in fishing is more worrying (Mous et al., 2000).

Different projects have been established to help conserve reef ecosystems. The Coral Reef Rehabilitation and Management Project (COREMAP) was established in 1998 (and has three phases for a total period of 15 years) and is aimed at protecting, rehabilitating and

1 To see the list, go to http:// www.iucnredlist.org 
sustaining the utilisation of coral reefs and associated ecosystems in Indonesia. This USD18,000,000 project is funded through a loan scheme from the International Bank for Reconstruction and Development, the Global Environmental Facility and the Asian Development Bank. COREMAP is aware of the importance of community-based Marine Protected Areas management; therefore, it has designed its program to involve communities in establishing such areas (Baitoningsih, 2009). However, Baitoningsih also concluded that the establishment of No Take Areas (NTA) for conservation, one of COREMAP's goals, was not understood by the communities, which resulted in their ineffective implementation (Baitoningsih, 2009).

The LRFF trade in the Spermonde Archipelago for the Hong Kong market started in the late 1980s with the establishment of a trade partnership between an entrepreneurial boat captain and a Makassarbased businessman, who exported lobster to Hong Kong (Fougères, 2009). At the Spermonde Archipelago, the LRFF trade operates through a commodity-chain network based on credit and debt and involving many agents (Meereboer, 1998; Fougères, 2005; Fougères, 2009). Commercial and employment relations in this commodity-chain network follow the patronage system that is common in South Sulawesi communities. These relations are often more of the type that has been described as that between patron and client (Meereboer, 1998).

The patron-client relationship can be characterised generally as an unequal (but theoretically non-binding) relationship between a superior (that is, a patron or leader) and a number of inferiors (that is, clients, retainers, or followers), based on an asymmetric exchange of services, where the de facto dependence on the patron of the clients, whose unpaid services may include economic obligations, paid or unpaid work, armed service, political support and other services, is counterbalanced by the role the patron plays as a leading figure for all the clients and by the assistance, including the monetary loans and protection, he or she provides when necessary (Pelras, 2000). 
Locally, this relation is known as punggawa-sawi. Of this, Pelras states: 'When the patronage relationship is not primarily set in a political context, but is primarily economic in character, the terms used in South Sulawesi are punggawa for the patron and sawi for the client' (Pelras, 2000).

It has been found that this patron-client or punggawa-sawi relation protects and sustains the practice of cyanide fishing because the punggawas, who want to be considered reliable and to continue to have a supply of fish, are willing to protect their sawis' fishing operations by bribing the police. Meereboer reported similar cases of bribery of the police by punggawas darat on one of the islands in the Spermonde Archipelago: the extent or likelihood of bribery of officials is related to the degree of closeness of punggawas darat to their clients (Meereboer, 1998: 269). In most cases, conservationists, bureaucrats and development workers stigmatise the fishermen and the punggawas darat as being responsible for cyanide use. In this case, the fishermen are the objects of law enforcement but fishermen and punggawas darat are the objects of police extortion. Celia Lowe reported similar attitudes to the Sama communities in the Togean Islands, which also depend on LRFF fishing and trade (Lowe, 2000).

Celia Lowe argued that the practice of using cyanide for fishing, which results in biophysical damage as well as damage to humans, could not be logically explained as the independent acts of a few misguided fishermen. She stated that the 'Togean people are caught within the matted fibres of market, law, bureaucracy, and identity that determine the patterns of who will fish with cyanide, who will profit the most by it and who will suffer the consequences' (Lowe, 2000). Erdmann argues that corruption is the reason behind the lack of law enforcement against cyanide fishing in Indonesia. The average coastal policeman views a boat carrying cyanide as a source of 'extracurricular funding' rather than a problem of law enforcement (Erdmann, 2001).

The findings of our empirical studies from 2007 to 2010 suggest that the use of cyanide by LRFF fishermen is still prevalent in the Spermonde Archipelago. According to the fishermen and the punggawas darat, 
LRFF catches are decreasing, which pushes the fishermen to exploit other fishing grounds, mostly in the reef area of Bone Bay and Kendari in Southeast Sulawesi. This state of affairs was also reported by Meereboer about a decade earlier, although without precise information on the location of new fishing grounds (Meereboer, 1998). There is a strong probability that the practice of using cyanide has spread to the new fishing grounds.

Sustainability in LRFF fishing and trade faces big challenges; on one hand, there is a lack of integrated effort, which goes deep into the problems of fisheries management in Indonesia, although there are some conservation and development programs supported by government, non-government organisations (NGO) and various stakeholders. On the other hand, there is a lack of reliable support for research that would provide more reliable information on the state of the ecosystem, that is, the size of fish stocks and reef conditions. In this paper, the framework of sustainability proposed by Norberg and Cumming will be used.

Sustainability is defined as the equitable, ethical and efficient use of social and natural resources. Equitable correlates with equitability among people with different economic and social status, from different geographical area of the earth or between today and future generation. Ethical means in concordance with today's (and future) human values, and efficient means that any decision made should be based on providing the least resource-greedy solution constrained by the above criteria (Norberg and Cumming, 2008).

There is a need to examine the sustainability of LRFF fishing and trade by delving deeper to find the real reasons why such unsustainable fishing practices are so widespread. The lack of understanding of the social dynamics underlying the LRFF fishing and trade, and the limited biological data and information, are the two main obstacles in the efforts to promote sustainable fishing practices.

This paper examines sustainability of reef fishing using the above framework of analysis by focusing on investigating the social networks 
underlying the LRFF fishing and trade in the Spermonde Archipelago. In examining the sustainability of LRFF fishing and trade, this paper focuses on two questions: first, to what extent do social networks support the fishing of, and trade in, LRFF in the Spermonde Archipelago? And, second, to what extent do such networks influence sustainability in LRFF fishing?

This paper employs social network analysis in examining sustainability in the LRFF fishing industry in the Spermonde Archipelago. It is argued that understanding the dynamics of the social networks, which are a result of interactions between different agents with different interests influenced by diverse circumstances (among them are the market, the local social structures, climate variability, biological conditions), is important in coastal fisheries management in general. It is the purpose of this paper to portray the social networks in LRFF fishing in the Spermonde Archipelago and to demonstrate how sustainability in LRFF fishing and trade can be understood through an analysis of these networks. It is the objective of this paper to provide better frameworks for promoting sustainability in reef fishery, particularly in Indonesia, through the elaboration and examination of social networks. In this regard, this paper also aims at providing tools for better coastal and fisheries management.

\section{Methods}

The material for this paper has been collected through fieldwork, using various social science methods, by interdisciplinary research groups comprising researchers and students from different disciplines. Since 2007, a team of researchers led by social scientists has worked on issues relevant to the achievement of more sustainable development of Indonesian coastal socioecological systems (Glaser et al., 2010).

The main study area is the coral-reef-based ecosystem of the Spermonde Archipelago, South Sulawesi, Indonesia, which is between $119^{\circ} 62^{\prime}$ ' E and 4'52'32" S, extends about 60 kilometres offshore, and comprises around 75 islands with fringing reefs as well as a large number of barrier 
and submerged patch reefs (Krause et al., unpublished manuscript). This area is broadly known as the centre of LRFF fishing in the eastern part of Indonesia and is supported by its proximity to the city of Makassar on the Sulawesi mainland, which is the nearest gate to international markets.

The author has been involved in research that includes two, joint, shipbased research excursions to the islands of the archipelago, along with a team of about 20 Indonesian and German researchers and students of anthropology, sociology, geography, political science, planning, fisheries economics, philosophy, communication studies and reef ecology. It has been a problem-focused, interdisciplinary cooperation, which took place in March and May 2009, and involved the active participation of local residents and resource users. Fieldwork with researchers and students from the Anthropology Department, University of Hassanuddin, Makassar, started at the end of 2007 on the islands of Barrang Lompo, Barrang Caddi, Bone Tambung, Badi, Sarappo Lompo and Karanrang. The fieldwork included ethnography, role-playing games, participatory mapping, semistructured interviews and in-depth interviews with members of local communities. There were interviews also with Makassar-based fish traders, government officials, university researchers and non-government organisations that are involved in LRFF fishing and trade issues.

At the end of 2009 and the beginning of 2010, the research included social-network mapping in reef fishery (LRFF fishing and coral and ornamental fishery). There has been growing attention and interest in examining better natural resources management using social networks analysis (Lauber et al., 2008; Marin and Berkes, 2010; Crona et al., 2010; Sandström and Rova, 2010; Adger et al., 2006). Lauber and colleagues reported that there is high value in tailoring strategies for involving stakeholders to meet different needs during a collaborative, community-based natural resource management project (Lauber et al., 2008). Borgatti proposes that there are at least two interesting aspects to be examined and elaborated in social network analysis: the types of ties, which correlate with the understanding of dyadic links between two agents; and the importance of structure, which correlates with the 
importance of the position of agents in the networks, where it can be seen as the function of patterns of relations among the members (the agents) or, at the individual level, the agent's outcomes and future characteristics can be seen as dependent, in part, on its position in the network structure (Borgatti, 2009). Taking these papers into account, this paper proposes the use of social networks analysis in fisheries management, especially in identifying the interests of various agents in networks in LRFF fishing and trade. In the network analysis literature, a network is formally defined as a collection of nodes and a collection of connections that join pairs of nodes, or in the language of mathematics, it is called a graph (Bohman, 2009). Hereafter, this paper will use the term 'agent' to represent the member of a social network that would be defined formally as a node.

\section{Figure 1}

\section{Map of Indonesia}

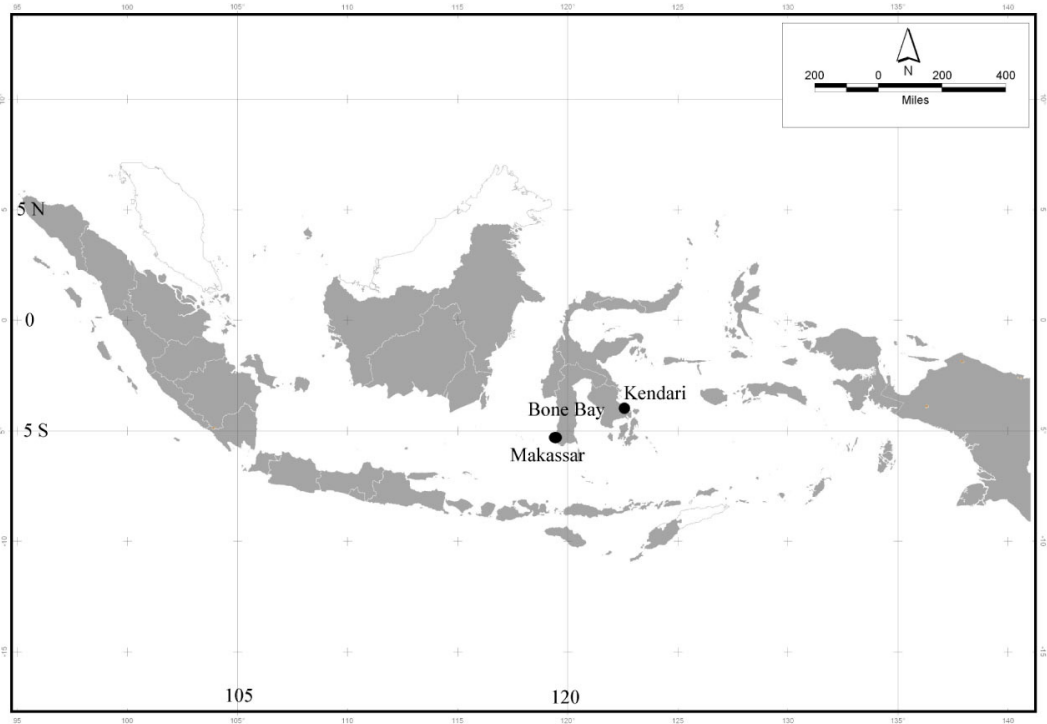




\section{Figure 2}

Study Site, Spermonde Archipelago, Indonesia

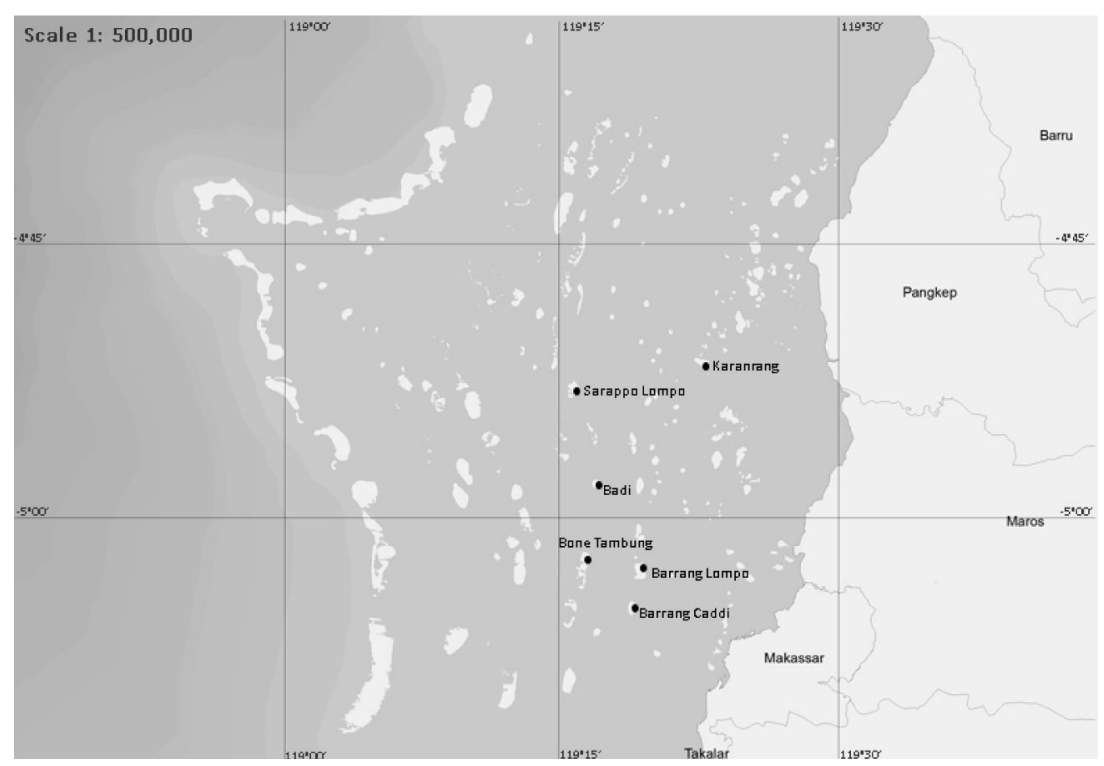

Understanding the whole picture of LRFF fishing and trade was the first step in the research and was done through literature studies as well as interviews with anthropologists, fisheries economists and coral scientists, all of whom have extensive experience of similar issues. The research is supported by observations of fishing practices and ethnographic fieldwork, as well as boat excursions involving people from different backgrounds.

Data on social networks were collected through fieldwork and interviews that used the snowball sampling approach. After obtaining data on punggawa-sawi systems, it is important to continue to identify which islands are the 'centres of activity' of LRFF fishing and trade, and to focus on collecting social network data (connections and relations) on particular islands. Data were also collected through interviews with Makassar-based entrepreneurs, who are known as bos [boss] by the 
island communities and who own the storage ponds where fish are kept before they are sent to Jakarta and Hong Kong.

\section{Results}

This section elaborates findings from research on social networks in LRFF fishing and trade in the Spermonde Archipelago. First, there is a description of the fish species traded and how they are commoditised because it is important to the explanation of the social networks involved. It will be followed by an elaboration of the various types of social networks in LRFF fishing and trade, which constitute the LRFF supply chain.

The LRFF trade in the Spermonde Archipelago includes different species (see Table 1). Reports by TRAFFIC East Asia, an NGO that monitors the species traffic, has identified at least nine species of reef fish that have become commodities in Hong Kong. Our work has found that at least five of them are from the Spermonde Archipelago. Recently we were able to identify three more species that have become commodities: Red-flushed Cod (Aethaloperca logaa; local name, sunu kwaci), Spotted Coral Trout (Plectropomus maculates; local name, sunu bone) and Plectropomus pessuliferus (local name, sunu merah).

Table 1

Reef fish from the Spermonde Archipelago traded in Hong Kong

\begin{tabular}{|l|l|l|l|}
\hline Local name & Indonesian & English & Latin \\
\hline Napoleon & Napoleon & $\begin{array}{l}\text { Napoleon Wrasse, } \\
\text { Humphead Wrasse }\end{array}$ & $\begin{array}{l}\text { Cheilinus } \\
\text { undulatus }\end{array}$ \\
\hline Sunu tikus & Kerapu tikus & $\begin{array}{l}\text { Polkadot Grouper, } \\
\text { High-finned Grouper, } \\
\text { Barramundi Cod }\end{array}$ & $\begin{array}{l}\text { Cromileptes } \\
\text { altivelis }\end{array}$ \\
\hline
\end{tabular}




\begin{tabular}{|l|l|l|l|}
\hline Sunu merah & $\begin{array}{l}\text { Kerapu merah/sunu } \\
\text { merah }\end{array}$ & $\begin{array}{l}\text { Coral Trout, Leopard } \\
\text { Grouper }\end{array}$ & $\begin{array}{l}\text { Plectropomus } \\
\text { leopardus }\end{array}$ \\
\hline Sunu merah & Sunu pappa & Polkadot Cod & $\begin{array}{l}\text { Plectropomus } \\
\text { areolatus }\end{array}$ \\
\hline Sunu merah & $\begin{array}{l}\text { Kerapu merah/sunu } \\
\text { merah }\end{array}$ & Violet Coral Trout & $\begin{array}{l}\text { Plectropomus } \\
\text { pessuliferus }\end{array}$ \\
\hline Sunu kwaci & Sunu kwaci & Red-flushed Cod & $\begin{array}{l}\text { Aethaloperca } \\
\text { logaa }\end{array}$ \\
\hline $\begin{array}{l}\text { Sunu macan/ } \\
\text { kerapu } \\
\text { lumpur }\end{array}$ & Sunu macan & Tiger Grouper & $\begin{array}{l}\text { Epinephelus } \\
\text { fuscoguttatus }\end{array}$ \\
\hline Sunu bone & Sunu bone & Spotted Coral Trout & $\begin{array}{l}\text { Plectropomus } \\
\text { maculatus }\end{array}$ \\
\hline
\end{tabular}

\section{Reef fish as commodities}

The LRFF that are fished and traded are categorised according to their weight, which differentiate their prices. The weight categories are 'baby', which includes all fish with a weight less than 0.6 of a kilogram (some punggawas set the maximum weight for this class at 0.3 kilograms), 'super', which includes all fish with a weight between 0.6 and 1.2 kilograms, and 'ekoran' (which in English means 'individual') or 'up', which includes all fish with a weight of more than 1.2 kilograms. Pricing rules apply for these groupings, which also vary among different islandbased punggawas. Fish categorised as baby are priced on weight or individually, it depends on the punggawa. Fish in the super category fetch the highest price in terms of unit weight. Fish in the ekoran or up category are priced individually. The prices and the weight standards vary slightly according to the different punggawas and boses. Table 2 shows the fish categories and pricing rules of one of the island-based punggawas. Different pricing and sizing rules will be elaborated in the next section. These rules are one of the reasons for any decision by islandbased punggawas to change their bos; they look for a bos who is not only 
generous in providing social security and support but also in enabling them to have a higher income through flexible sizing and pricing rules.

Table 2

Fish categories and the prices set by island-based punggawas for various reef fish species traded

\begin{tabular}{|l|l|l|l|}
\cline { 2 - 4 } \multicolumn{1}{c|}{} & \multicolumn{1}{c|}{$\begin{array}{c}\text { Baby } \\
\text { (IDR/kg) }\end{array}$} & \multicolumn{1}{c|}{$\begin{array}{c}\text { Super } \\
\text { (IDR/kg) }\end{array}$} & $\begin{array}{c}\text { Ekoran } \\
\text { (IDR/individual) }\end{array}$ \\
\hline Sunu tikus & 75,000 & 220,000 & 350,000 \\
\hline Sunu karang & 55,000 & 130,000 & $180,000-250,000$ \\
\hline Sunu bone & 35,000 & 60,000 & 75,000 \\
\hline Napoleon & & & 350,000 \\
\hline
\end{tabular}

The fish are caught and traded through commodity supply-chain networks, involving different agents, from the islands to the market in Hong Kong. There are three types of networks in LRFF fishing and trade: the fishing network, concerned with catching the fish; the marketing network, concerned with the transport of fish to the next agent in the chain, and the prosecution insurance network, which is to guarantee that those in the trade do not face prosecution for using cyanide, the use of which is illegal.

\section{Fishing network}

The fishing network in the LRFF trade consists of two types of agents, the punggawa (the patron) and the sawi (the client), which together form the social structure called punggawa-sawi. The punggawas provide fishing boats and have access to information about the demand: the sawis are the fishermen who sell their catches to their patrons. This structure survives through the traditional or institutional debt arrangements. 
As explained previously, LRFF fishing in the Spermonde Archipelago is very much subject to the monsoonal climate. During the 'west season' [musim barat], from October to March each year, fishermen cannot go fishing because the sea is so dangerous. They have limited capital and their indebtedness to their punggawa causes them to become dependent on him. During the 'east season' [musim timur] from April to September, fishermen are able to fish again but they have to sell their fish to their punggawa at a lower than market price. The punggawa provides boats for his fishermen, the capital needed for fishing and, as well, provides them with a subsistence income and security, especially during the west season (the off season). The local communities sometimes refer to the punggawas who live on the islands (although some live in Makassar) as punggawa darat [land punggawa], to differentiate them from a punggawa laut [sea patron] who is the captain of a bigger boat (locally known as a joloro'). The term for client of a punggawa darat is paboya, which means 'fishing fleet', so paboya can refer to one fisherman or to a group of fishermen in the same boat led by a punggawa laut. A punggawa darat maintains control over his paboya by keeping them indebted to him.

There are two types of boat used for fishing; each type corresponds to the mode of fishing and the fishing gear used, as well as defining the social networks. The small boat, called a lepa-lepa, is usually made of fibreglass and equipped with a small-capacity motor (24 or so horsepower) and is worked daily by a single fisherman. Fishermen who use a lepa-lepa forage in proximity to their home island in the Spermonde Archipelago because the boat's fuel tank has limited capacity. The boat and its equipment are on loan from the punggawa darat to his sawi, once they agree that they have a business partnership. A fibreglass lepa-lepa and its equipment cost the punggawa darat around IDR7,000,000 (USD700). It is the responsibility of a punggawa to provide his sawi (fisherman) with a subsistence allowance, which for this type of boat is around IDR100,000 (USD10) per fishing trip, and is used for fishing gear (see Table 3). The fishermen have to provide their own petrol, food, coffee and cigarettes, and for these needs they are able to borrow some more, about IDR50,000 
(USD5) a day. They use a hand line but the catch rate is very low; to catch one or two fish might take three, sometimes more, days. Each day fisherman start early in the morning, around 5 o'clock, and return to their island at around 3 o'clock in the afternoon. They are obliged to sell the fish they catch to their punggawa darat at their agreed price (which is usually lower than the price they might get from other punggawas darat). A punggawa darat deducts the amount of any loan repayment from the payment to the fisherman.

During musim barat or the west season, when the seas are rough, some punggawas darat with his sawis forage farther afield to other fishing grounds, like the reef areas of Kendari, South-east Sulawesi or Sinjai at Bone Bay, South Sulawesi. A punggawa darat takes his sawis and their lepa-lepas in his big carrier boat (there might be up to 30 lepa-lepas) and sails to farther fishing grounds beyond Spermonde. This foraging farther afield is known as sawakung and refers to a venture in which a punggawa darat invests an amount of money (it has been observed that the amount of investment varies between IDR40,000,000 and IDR100,000,000 (USD4000 and USD10,000) to send his fleet to new fishing grounds. Sawakung might take several months, usually starts in October or November, and continues until February or March when the fleets return to Spermonde.-

The punggawa darat is responsible for all his sawis' needs, which include food, cigarettes and petrol, and they also provide cash for the families of his sawis, who remain at home. Each sawi's family receives around IDR1,000,000 to IDR2,000,000 (USD100 to USD200) during this sawakung period. However, it is also known that sawakung is also practiced in the proximity of the Spermonde Archipelago, especially during the musim timur or the east season. The favourite areas for sawakung in the Spermonde Archipelago are the reef areas of Jangangjangangang, north-west of Makassar (see Figure 1), about five to six hours away where sawakung can last from several days to three weeks. Like the normal contract-fishing practice, during the sawakung, the sawis have to sell their catch to their punggawas darat at the agreed 
price; the money they earn has an amount deducted to repay any loan (see Table 3). One punggawa darat said that it is his strategy to take his paboyas with his carrier boat to more distant fishing grounds and provide them with the equipment they need because, in this situation, the paboyas will not be able to return home because it is too far; they have no option but to catch more fish. A punggawa darat will only return to the Spermonde after having caught a planned amount of fish. Imlek, the Chinese New Year, which is usually at the end of January or the beginning of February, is the period when the price of fish doubles or triples. Therefore, the whole fleet will want to catch more fish at this time to meet the demand and to make a bigger profit.

Table 3

Support (loans) from punggawa darats to their sawis who use a lepa-lepa

\begin{tabular}{|l|l|}
\hline Type of support & $\begin{array}{l}\text { Amount } \\
\text { IDR (USD) }\end{array}$ \\
\hline Boat and motor & IDR7,000,000 (USD700) \\
\hline Nylon & IDR 4,000 (USD0.40) \\
\hline Gloves & IDR 3,000 (USD0.30) \\
\hline Tymbal & IDR3,000 (USD0.30) \\
\hline Hooks (1 pack) & IDR15,000 (USD1.50) \\
\hline Wire & IDR20,000 (USD2.00) \\
\hline Little buoy & IDR5,000 (USD0.50) \\
\hline $\begin{array}{l}\text { Petrol and food, coffee and } \\
\text { cigarettes (daily) }\end{array}$ & IDR50,000 (USD5.00) \\
\hline
\end{tabular}

The second type of boat used in LRFF fishing is called a joloro', and it has a crew of three to five and one captain (punggawa laut). A joloro' is a bigger boat that a lepa-lepa and is equipped with a more powerful 
motor (our interviewees confirmed that the motor used has much the same capacity as an automobile). A joloro' with its crew can forage over larger areas and operate for three to four days at a time before returning to their island bases. Punggawas darat provide this group with support for their fishing expeditions. Around IDR150,000 (USD15) per day is provided by punggawas darat for fuel, food, coffee and cigarettes. The fishing gear and boats are on loan from punggawas darat to punggawas laut. One joloro' with a motor costs around IDR30,000,000 (USD3000), and is treated as a debt of a punggawa laut to a particular punggawa darat. This debt might increase significantly because usually the punggawas laut need to borrow more for operating a joloro'. The fishermen on a joloro' use bubus to catch LRFF, which requires them to be skilled divers. Using bubus, fishermen might catch up to 15 fish per expedition. However, a combination of diving skills and working in a group allows other fishing methods, which enables them to increase the size of their catch. A joloro' is big enough for air compressors to be carried, which let the divers dive deeper and for longer. Compressors might also be used for catching trepang (Sea Cucumber) in the area (Mánez and Ferse, 2010). However, as described earlier, fishermen do not catch fish using bubus only, they also use cyanide (potassium or sodium cyanide) (Chozin, 2008; Glaser et al., 2010a; Glaser et al., 2010b; Fougères, 2009). Using cyanide enables fishermen to catch more fish in a shorter time. As also reported by Barber and Pratt (1997), cyanide is used to catch particular fish species to supply the high end of the market, that is, those fish in high demand that fetch a high price.

One of the divers interviewed said that the use of cyanide increases the chances of catching highly valued fish like sunu tikus, which live at a depth of 20 metres and are hard to catch because they hide in the reef. With cyanide, it is possible to bring back about 10 to 15 such fish from a three-to-four-day expedition. There is always a risk that the catch will be confiscated by the authorities because using cyanide for fishing is illegal (see Table 4). However, using bubus is the most common method 
on the island of Bone Tambung; only one punggawa darat there uses cyanide (Deswandi, 2011).

Table 4

\section{Comparison of lepa-lepa and joloro'}

\begin{tabular}{|c|c|c|}
\hline & Lepa-lepa & Joloro' \\
\hline Number of fishermen & One. & $\begin{array}{l}\text { A captain (punggawa } \\
\text { laut) and a crew of three } \\
\text { to five. }\end{array}$ \\
\hline Operational costs & $\begin{array}{l}\text { IDR50,000 (USD5) per } \\
\text { day for the fuel, food, } \\
\text { coffee and cigarettes. }\end{array}$ & $\begin{array}{l}\text { IDR150,000 (USD15) } \\
\text { per day for fuel, food, } \\
\text { coffee and cigarettes. }\end{array}$ \\
\hline $\begin{array}{l}\text { Number of days per } \\
\text { expedition }\end{array}$ & One. & Three to four. \\
\hline Operational area & $\begin{array}{l}\text { Reef areas near their } \\
\text { island. }\end{array}$ & $\begin{array}{l}\text { Reef area beyond their } \\
\text { island. }\end{array}$ \\
\hline Fishing gear & Hand line. & $\begin{array}{l}\text { Hand line, cyanide, } \\
\text { bubus. }\end{array}$ \\
\hline Supporting tools & Small capacity motor. & Larger capacity motor. \\
\hline $\begin{array}{l}\text { Number of fish caught (in } \\
\text { the Spermonde area) }\end{array}$ & $\begin{array}{l}\text { One or two fish after } \\
\text { three to five days. }\end{array}$ & $\begin{array}{l}\text { Fifteen fish per } \\
\text { expedition with bubus, } \\
\text { or } 15 \text { to } 20 \text { if cyanide is } \\
\text { used. }\end{array}$ \\
\hline
\end{tabular}

Punggawas darat make decisions on which paboyas to support and work with during the musim timur and musim barat and they also make the decision to go to other fishing grounds during the west season and how much to invest. A punggawa darat is also responsible for mitigating or removing the risks faced by their crew members, including the risk of being caught by the police for using cyanide. A punggawa darat should be able, in whatever way, to protect his paboyas from having their catch 
confiscated. In this and other ways, it is important for punggawas darat to build a reputation for reliability and trustworthiness in the minds of the fishermen. Punggawas darat choose the punggawas laut to work with. A punggawa laut has the knowledge needed for LRFF fishing and trade; for example, the whereabouts of good fishing grounds that should provide more fish. Punggawas laut are responsible for their boat's crew, who are considered to be their sawis.

Because of a dispute, disagreement or other reason, a punggawa laut (and individual fisherman too) might sever their contract or agreement with their current punggawa darat and come to an agreement with another punggawa darat. This may be done if there is no debt attached to the contract or, if there is, that the debt be taken over by the 'new' punggawa darat. To break these patron-client arrangements requires that there be no debt remaining (Meereboer, 1997). Such disputes and ruptures create the dynamism in the LRFF social networks in the Spermonde Archipelago, but the basic punggawa-sawi structure remains. However, these changes in patron-client relations do have an influence on the sustainability of LRFF fishing; connections can be unmade quickly but it takes a while for trust and loyalty to be built in newly formed relations and without trustful, loyal patronage, the risks and consequences of using cyanide are much greater.

It has been found that there are two types of ties between a punggawa darat and his paboya. A punggawa darat will choose his paboya from within his close family (for example, a son or nephew), or extended family (based on kinship), to operate his carrier boat during the sawakung time to ensure strong control over his property and operations. Trust is the foundation of the choice of paboya by a punggawa darat: trust is defined as the willingness of paboyas always to sell their fish to their punggawa darat and to not cheat by selling to other punggawas darat, even if the other's prices are better. On the other hand, a paboya might choose to work with a particular punggawa darat for at least two reasons: generosity of the punggawa darat in lending money and materials; and flexibility in fish sizing rules. (Fish sizing rules are explained in the next 
section.) It is also known that there are different treatments by punggawas darat of some paboyas that are based on performance (number of fish caught and loyalty), and these inconsistencies at some point can create competition and tension among paboyas. It can be seen that there is horizontal mobility among the punggawas laut and punggawas darat. A bos who has newly engaged a selected punggawa darat will be keen to rid the punggawas darat of his debts from a former engagement, because he sees this new engagement as an investment that will bring a better supply of fish and greater profits. Similarly, a new punggawa darat will be also keen to pay off the debts of some punggawas laut to their current punggawa darat because he believes it will increase his profits.

As reported by Fougères, capturing reef fish alive poses greater challenges than for other piscine commodities because fish can swim rapidly away when pursued or hide in the coral. Divers have to dive down to the reef and get close enough to the fish to squirt them with cyanide solution. Once the fish are caught, to ensure that they survive in shallow water, the paboyas relieve the air bladders of the fish by carefully inserting a hypodermic needle to allow air to escape (Fougères, 2008).

\section{Marketing networks}

The marketing networks in LRFF fishing comprise the various agents who interact: the punggawas darat, who are based on the islands and are responsible for delivering fish to their bos; the boses, who are based in the city of Makassar and responsible for delivering fish to the exporter; the exporters, who are based in Jakarta and are responsible for delivering fish to the importers; and the importers, who are based in Hong Kong and deliver fish to restaurants.

Punggawas darat deliver their catches to their bos and are paid according to pricing and sizing rules. Punggawas darat and boses have various strategies to minimise the economic risk in the LRFF trade. Fish death is a big risk for punggawas darat and for boses: dead fish fetch a very low price, about one fifth of the live fish price. One of the interviewees 
reported that for each dead fish, they receive IDR110,000 (USD11) per kilogram instead of around IDR400,000 (USD40) per kilogram during the normal times or IDR200,000 (USD20) per fish instead of IDR600,000 (USD60) per kilogram during Imlek. Fougères argues that getting LRFF from ocean to markets necessitates greater technological complexity and economic risk than for other commodities harvested for export from Indonesia's reefs because LRFF need to be kept in clean, cool, oxygen-rich seawater to survive (Fougères, 2008). After LRFF are caught, they are at risk of dying for at least two reasons: their treatment during storage, which is related to the quality of the water and the use of cyanide; and transport, that is, the time it takes to reach their destination, the treatment and handling of the fish and their packaging.

There are different strategies to minimise the chances of fish dying: reducing the time taken in handling the fish; treating the fish with different biological and chemical agents; and using special packaging when transporting the fish. Once fish have been caught, they are deposited in the paboya boats, transported to their punggawa darat's base in the islands, classed according to species and size, and weighed. Fish are stored at the punggawa darat's place for a maximum of two days (usually one day only, or overnight) for two reasons: to refresh the fish and to collect fish from other paboyas before transport to Makassar. To refresh them, each fish is immersed for several minutes in fresh water in which is dissolved what is known locally as obat kuning (sodium nifrustyrenate; an antiseptic and antibacterial agent), which is believed to prevent fish getting infections from injuries and scratches received during their catching, handling and transport. Each fish is then injected with terramycin, an antibiotic that can be bought in Makassar for IDR10,000 (USD1.00) per bottle: a bottle has enough for injecting 50 to 75 fish. Punggawas darat and boses believe that terramycin kills the bacteria in fish and that this will fortify them. Fish are then kept in ponds ready to be transported to Makassar the next morning. After being sized, and priced accordingly, punggawas darat pay their paboyas. The risk of fish dying then is that of the punggawa darat. 
At a bos's place in Makassar, the same procedures apply; incoming fish are classed by species, weighed and sized. Then they are immersed in fresh water and twice injected with terramycin and vitamin B complex; in the morning when the fish arrive and in the afternoon. The boses pay the punggawa darat directly after sizing the fish, which are kept overnight in ponds. The next morning, before being packed, the fish are anaesthetised with rotenone, a naturally occurring chemical obtained from the roots of tropical plants. Rotenone has insecticidal, acaricidal (spider killing) and piscicidal (fish killing) properties, and is classified by the World Health Organization as moderately hazardous (PAN-UK, 2001). Anaesthetised fish are stored in plastic bags filled with seawater and oxygen. Four to six fish are put in the one plastic bag and then stored inside a styrofoam box (known locally as a koli) with ice to keep the temperature at $18^{\circ} \mathrm{C}$. Each koli weighs about five or six kilograms. Each Makassar-based bos delivers about 40 kolis per day. Once the fish are at the bos's place, the risk of fish dying is his.

Table 5

Fish prices from various middlemen during the normal season

\begin{tabular}{|l|l|l|}
\hline \multicolumn{1}{|c|}{ Species } & \multicolumn{1}{|c|}{$\begin{array}{c}\text { Price at } \\
\text { punggawa darat } \\
\text { (IDR) }\end{array}$} & \multicolumn{1}{|c|}{$\begin{array}{c}\text { Price at Makassar } \\
\text { (IDR) }\end{array}$} \\
\hline Kwaci hitam & 30,000 & 80,000 \\
\hline Kwaci merah (pongah-pongah) & 50,000 & 100,000 \\
\hline Sunu merah (baby) & 100,000 & 150,000 \\
\hline Sunu merah (super) & 400,000 & 450,000 \\
\hline Sunu merah (up) & 285,000 & 335,000 \\
\hline Pappa & 70,000 & 100,000 \\
\hline Sunu tikus (super) & 400,000 & 600,000 \\
\hline Sunu tikus (baby) & 175,000 & 225,000 \\
\hline
\end{tabular}




\begin{tabular}{|l|l|l|}
\hline Sunu tikus (up) & 500,000 & 600,000 \\
\hline Sunu macan (super) (sold dead) & 30,000 & 80,000 \\
\hline Sunu macan (super) & & 50,000 \\
\hline Sunu macan (up) & & 50,000 \\
\hline Napoleon & 275,000 & 325,000 \\
\hline Sunu bone (baby) & 40,000 & 60,000 \\
\hline Sunu bone (super) & 100,000 & 130,000 \\
\hline Sunu bone (up) & 130,000 & 160,000 \\
\hline Sunu hitam (super) & 170,000 & 190,000 \\
\hline Moso kembang or kerapu lumpur & 20,000 & 30,000 \\
\hline Kerapu tiger & 20,000 & 30,000 \\
\hline
\end{tabular}

A Makassar-based bos is bound to his punggawas darat on the basis of trust. He arranges different loans for each of his punggawas darat; these can range from IDR100,000,000 (USD10,000) to IDR500,000,000 (USD50,000). One punggawa darat interviewed said that there are two reasons for his connecting to his Makassar-based bos: power, because he believes that a good bos is the one with power and who has links to various agents and that this will help to keep the business running despite illegal practices; and generosity, because he perceives a good bos as one who is generous with money and materials in his support (with loans and grants) for his punggawas darat.

Punggawas darat have to maintain good relations with their boses by delivering the quota of fish demanded. Boses treat punggawas darat differently according to their results. Support by a bos to a punggawa darat varies in amount and type and includes money, loans, boats and machinery. One Makassar-based bos is known to support half of the necessary bribes by his punggawas darat to the police in order to avoid prosecution for using cyanide in their fishing. 
The exporters in Jakarta, mainly Indonesian ethnic Chinese, provide information on the demand for LRFF. They maintain their lines of communication with importers and restaurant owners in Hong Kong and China. At the beginning of the LRFF trade, the exporters, also known as bosses, provided the punggawas darat with the necessary credit to start forming a team of fishermen to catch the fish. However, with time, some punggawas darat managed to become independent of their creditors and to organise their business independence and to become boses (Fougères, 2009). Punggawas darat depend on their boses and on Jakarta-based exporters to access the Hong Kong market. However, there is one Makassar-based bos who has been able to establish his own direct connections with the Hong Kong market.

The price Jakarta-based exporters charge for each kilogram of fish delivered to Hong Kong is double the price they pay to Makassar-based boses. However, the exporters are also subject to the risk of the fish dying. For dead fish, the exporter is paid one fifth of the live fish per kilogram price by the Hong Kong importer.

\section{Prosecution insurance network}

High demand for LRFF from the Hong Kong market, especially during the Chinese New Year celebrations, has helped develop LRFF fishing to be the lucrative industry it is, especially for the middlemen from punggawas darat based on the islands to the fish importers in Hong Kong.

LRFF fishing involves greater technological complexity and economic risks compared with other marine commodities. The fish in high demand are hard to catch; they live in coral reefs at different depths. Live fish need to be delivered from ocean to market quickly to minimise losses from fish dying. Boses and punggawas darat provide fishermen with air compressors, which permit them to dive longer and deeper, and this enables them to catch more fish. This encourages the fishermen to maximise their catch and to minimise the time spent so they can pay their debt to punggawas darat and earn a higher income. The use of potassium 
and sodium cyanide is prevalent in the LRFF fishing because the catch rate when using cyanide is much higher than when more environmentfriendly fishing gear is used, like bubus or hand lines.

The Indonesian fisheries law 31 of 2004 prohibits the use of any chemical, biological agent and explosive, or any other method or equipment that might threaten the ecosystem, and transgressions are subject to punishments of up to six years in prison or fines of IDR1.2 billion (USD120,000). The Pangkep Regency District Regulation 10 prohibits the collection and destruction of coral reefs in the area of Pangkep Regency, South Sulawesi. Punishment may include up to six months in prison or a fine of IDR5,000,000 (USD500).

The use of cyanide depends on the willingness and readiness of a bos to deal with the risk of prosecution through bribery. Those boses who engage fishermen who use cyanide are those who have prosecution insurance networks with various authorities, mainly with the police and the navy but sometimes also with the officials from the Kementrian Kelautan dan Perikanan (Ministry of Marine and Fisheries), are the ones who engage cyanide fishermen. These networks connect the punggawas darat and boses to, mainly, the police and the Indonesian navy. Paboyas use cyanide when they are sure that their punggawa darat and bos will arrange bribes to protect them from having their catch confiscated by the police or navy. Boses protect their punggawas darat and paboyas by giving money regularly to the authorities. Two interviews with the righthand-men of two different boses in Makassar confirmed that they have to make regular payments to the police commandant, and to each of the police who regularly visit their fish ponds at Makassar. The interviewees also confirmed that they give money to the navy commandant and to each of the naval officials who regularly visit the ponds. 
Table 6

Prosecution insurance expenses

\begin{tabular}{|l|l|}
\hline $\begin{array}{l}\text { Prosecution insurance } \\
\text { agents }\end{array}$ & Amount \\
\hline Water police & $\begin{array}{l}\text { IDR50,000 - 100,000 (USD5 - 10) per person per } \\
\text { visit. }\end{array}$ \\
\hline Commandant of water police & $\begin{array}{l}\text { IDR1,000,000 - 2,000,000 (USD100 - 200) per } \\
\text { month. }\end{array}$ \\
\hline Navy & IDR50,000 (USD5) per person per visit. \\
\hline Naval commandant & $\begin{array}{l}\text { IDR1,000,000 - 2,000,000 (USD100 - 200) per } \\
\text { month. }\end{array}$ \\
\hline
\end{tabular}

Paboyas confirmed that the decision to use cyanide is theirs; there is no order from their punggawa darat or bos; however, punggawas darat and boses do not prohibit the use of cyanide. One of a bos 's righthand-men reported that the fine for using cyanide when caught by the police or navy is around IDR200,000,000 (USD2000). This fine is paid collectively by punggawas darat and boses. Both use bribery to ensure that the matter goes no further than the police or naval authorities: were the case to go to court, the penalties would be greater.

Paboyas who catch Napoleon Wrasse are also open to having their catch confiscated. The Indonesian Ministry of Agriculture issued ministerial decision 375/Kpts/IK.250/5/95 banning the catching of Napoleon Wrasse though with some exceptions (supported by permission from the Minister of Agriculture and the Director-General of Fisheries) for research, knowledge development, and mariculture reasons, and for traditional fishermen who use non-destructive fishing gear. However, there are two boses in Makassar who have obtained permission to catch Napoleon Wrasse. It is reported by the right-hand-man of one of those boses that it costs hundreds of millions of rupiahs to obtain 
such permission. One of the paboyas of an influential bos reported that he was caught by the police catching Napoleon Wrasse, but his bos 'released' him by bribing the police with IDR35,000,000 (USD3500), and that this happened twice. Local fishermen believe there is an agreement between the various agents for insurance from prosecution, that each has a particular patch or what is known locally as a kavling (from the Dutch, kaveling), which literally means parcels of land. It seems the agents have agreed not to encroach on the kavling of other groups, police or navy; in other words, once a bribe has been paid it will not have to paid again for the same service, although sometimes punggawas darat and boses have to pay to more than one group.

\section{Reef Fishery Social Networks: a Graphical Model}

Social networks in LRFF fishing in the Spermonde Archipelago can be drawn as a conceptual graphical model as shown in Figure 3. There are at least 15 agents involved in LRFF fishing networks, from catching the fish to when they are delivered in Hong Kong markets (see Table 7.

Table 7

Agents and their roles in LRFF fishing and trade networks

\begin{tabular}{|l|l|l|}
\hline No. & Agent & Role in LRFF fishing and trade \\
\hline 1 & Water police & $\begin{array}{l}\text { Patrol fishing grounds to enforce laws that prohibit } \\
\text { destructive fishing practices and the export of } \\
\text { specified fish species. However, water police receive } \\
\text { bribes from punggawas darat and boses to avoid } \\
\text { prosecution for using cyanide and exporting Napoleon } \\
\text { Wrasse. }\end{array}$ \\
\hline
\end{tabular}




\begin{tabular}{|c|c|c|}
\hline 2 & Police & $\begin{array}{l}\text { Patrol fishing grounds to enforce laws that prohibit } \\
\text { destructive fishing practices and the export of } \\
\text { specified fish species. Police receive bribes from } \\
\text { punggawas darat and boses to avoid prosecution for } \\
\text { using cyanide and exporting Napoleon Wrasse. }\end{array}$ \\
\hline 3 & Navy & $\begin{array}{l}\text { Patrol fishing grounds to enforce laws that prohibit } \\
\text { destructive fishing practices and the export of } \\
\text { specified fish species. Navy officials receive } \\
\text { money from punggawas darat and boses to avoid } \\
\text { prosecution for using cyanide and exporting Napoleon } \\
\text { Wrasse. }\end{array}$ \\
\hline 4 & Prosecutor & $\begin{array}{l}\text { Prosecute those caught breaking the law. However, } \\
\text { prosecutors can be bribed by boses for those cases } \\
\text { brought to court because of the use of cyanide. }\end{array}$ \\
\hline 5 & $\begin{array}{l}\text { Workers for } \\
\text { punggawa darat }\end{array}$ & $\begin{array}{l}\text { Size the fish from paboyas. They are important } \\
\text { agents in determining which fish go to which } \\
\text { size category and can be bribed by paboyas or } \\
\text { punggawas laut to loosen the sizing rules, which } \\
\text { allows for greater profit. }\end{array}$ \\
\hline 6 & Punggawa darat & $\begin{array}{l}\text { Provide paboyas with fishing gear and monetary } \\
\text { support. Ensure that the fish are in good condition } \\
\text { to get a better price. Provide protection against } \\
\text { prosecution for using cyanide or catching banned } \\
\text { Napoleon Wrasse. }\end{array}$ \\
\hline 7 & Makassar-based bos & $\begin{array}{l}\text { Provide punggawas darat with fishing gear and } \\
\text { monetary support. Ensure that the fish are in good } \\
\text { condition to ensure a better price. Provide protection } \\
\text { against prosecution as the result of using the cyanide } \\
\text { or catching Napoleon Wrasse. }\end{array}$ \\
\hline 8 & $\begin{array}{l}\text { Individual fisherman } \\
(\text { paboya) }\end{array}$ & Catching fish. \\
\hline 9 & $\begin{array}{l}\text { Punggawa laut } \\
(\text { paboya })\end{array}$ & $\begin{array}{l}\text { Skippering a boat, choosing gear, choosing fishing } \\
\text { locations, choosing sawis laut for expeditions and } \\
\text { catching fish. }\end{array}$ \\
\hline
\end{tabular}




\begin{tabular}{|l|l|l|}
\hline 10 & Sawi laut (paboya) & Catching fish. \\
\hline 11 & $\begin{array}{l}\text { Workers for } \\
\text { Makassar bos }\end{array}$ & $\begin{array}{l}\text { Size, weigh and categorise the fish received from } \\
\text { punggawas darat. They determine which fish go to } \\
\text { which size category and can be bribed by paboyas } \\
\text { or punggawas laut to loosen the sizing rules, which } \\
\text { allows for greater profit. }\end{array}$ \\
\hline 12 & $\begin{array}{l}\text { Quarantine by } \\
\text { Kementrian } \\
\text { Kelautan dan } \\
\text { Perikanan (Ministry } \\
\text { of Marine and } \\
\text { Fisheries) }\end{array}$ & $\begin{array}{l}\text { Fish sampling for biological testing for pathogens } \\
\text { and bacteria. A bos has to pay between IDR5000 and } \\
\text { 7000 (USD0.50 - 0.70) per kilogram of fish to get a } \\
\text { clearance letter. }\end{array}$ \\
\hline 13 & $\begin{array}{l}\text { Jakarta-based } \\
\text { exporter }\end{array}$ & $\begin{array}{l}\text { Ensure that the fish are in good condition to get a } \\
\text { better price. Ensure that fish can be exported to Hong } \\
\text { Kong without any problem. }\end{array}$ \\
\hline 14 & $\begin{array}{l}\text { Hong Kong-based } \\
\text { importer }\end{array}$ & $\begin{array}{l}\text { Ensure that the fish may enter Hong Kong and be } \\
\text { distributed to the restaurants. }\end{array}$ \\
\hline 15 & $\begin{array}{l}\text { Hong Kong } \\
\text { restaurant }\end{array}$ & $\begin{array}{l}\text { Provide aquariums for displaying the fish before } \\
\text { selling them to the end consumer. }\end{array}$ \\
\hline
\end{tabular}

One of the important features of the social networks in LRFF fishing and trade in the Spermonde Archipelago is the increased self-esteem and higher social position that comes from making a pilgrimage to Mecca, known as going on a Hajj. Those who do so may, on their return, use the title Haji. To go on a Hajj is one of the five pillars of Islam and is the duty of every Muslim to do so if they are able to afford it. In Spermonde, a person titled Haji is considered a noble and respectable person. The late 1990s and early 2000s is the period when the a great number of people from the Spermonde Archipelago went on a Hajj, most of them are punggawas darat. The cost of going on a Hajj ranges from IDR20,000,000 to IDR48,000,000 (USD2000 to USD4800) depending on the type of Hajj. The Makassar-based boses especially (but not those of Chinese ethnicity), often support their punggawas 
darat to go on a Hajj. This is seen locally as a prize or reward from a bos to his punggawa darat and this generosity is a representation of the power they have. Quite a number of punggawas darat go on a Hajj more then once, which give them greater cause for pride and recognition from their community.

Figure 3

Conceptual Graphical Model of Social Networks in LRFF fishing in the Spermonde Archipelago, Indonesia

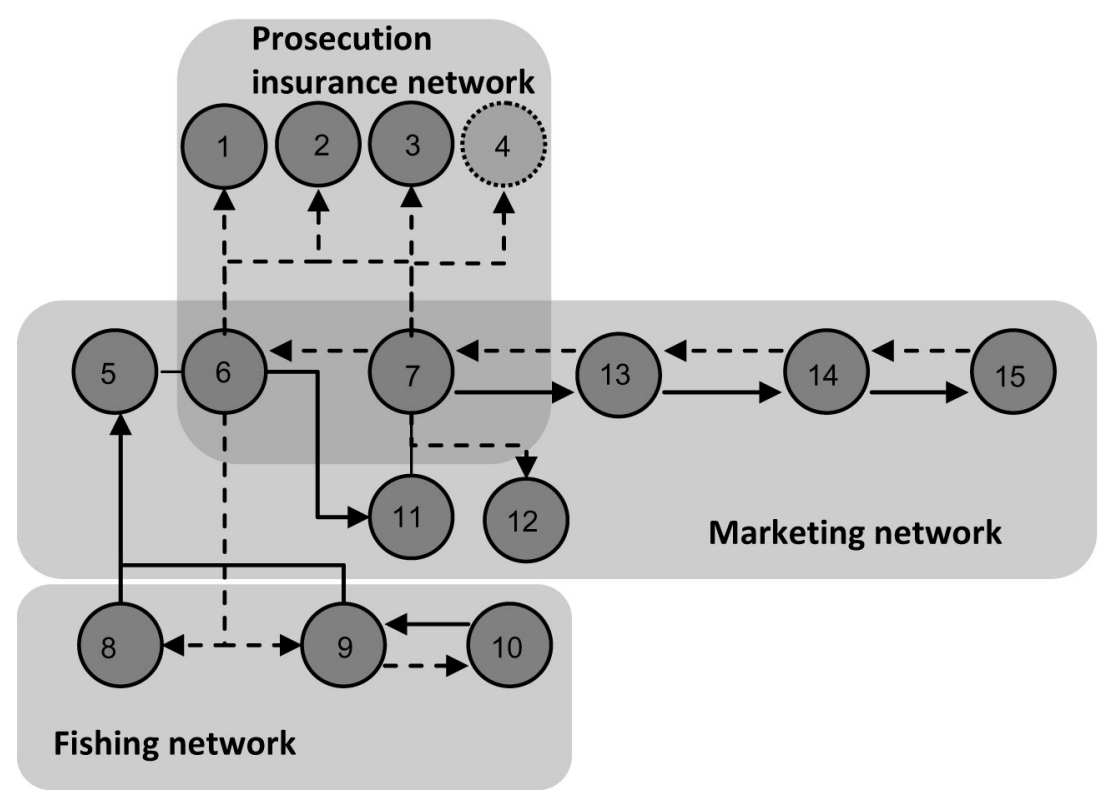

\section{Conclusion and Discussion}

To what extent do social networks support the fishing of LRFF and its trade in the Spermonde Archipelago?

As argued by Fougères (2009), the biophysical forms of LRFF and their need to have, or to live in, clean, cool, oxygen-rich seawater means 
that to catch and keep them alive until they reach the end-market entails complex technology and a greater economic risk compared with other marine commodities taken from reefs in the Archipelago. These conditions have caused particular social networks to develop that support LRFF fishing and trade through the establishment of debt relations, profit maximisation, and corruption. There are three types of networks in LRFF fishing and trade: fishing networks, marketing networks, and prosecution insurance networks.

Debt underlies the fishing networks because paboyas have limited options apart from fishing to earn a livelihood, especially during the west season. Profit maximisation is the driver in the marketing networks: punggawas darat and boses have the capacity to invest in and establish the costly and high-risk LRFF trade, which allows them to supply what the market demands. Supplying the demands of the market and making higher profits can only be achieved by exploiting more fishing grounds and increasing the size of the catch. For this reason, the illegal use of cyanide is prevalent and leads to the establishment of prosecution insurance networks that organise corruption.

To what extent do such networks influence the sustainability of reef fishery?

By examining the social networks in LRFF fishing, it can be identified that the challenges of sustainability in reef fisheries are rooted in the debt traps that characterise the fishing networks, the high profit making which characterises the marketing networks, and the corruption that is characteristic of the prosecution insurance networks. The profit maximisation from fishing and the creation of dependencies through debt have been the push factors for high exploitation, the use of cyanide, and foraging to farther fishing grounds, which is facilitated by the common practices of corruption.

The paboyas reported that they are having more difficulty in finding fish in the Spermonde area. The punggawas darat are having to invest 
more money to move to other fishing grounds in the area of Kendari and Bone Bay, especially during the musim barat. Paboyas and punggawas darat reported that in the past two years, there have been changes to sizing rules. The minimum limit of super size has been changed from 1.3 kilograms to 1 kilogram. There have been fewer deliveries, that is, production has been decreasing. One of the boses reported that in the past year his organisation had been able to deliver 10 to 20 kolis only per day to Jakarta, compared to the delivery rate three years before (up to 120 kolis per day). It has also been found that the notion of 'sustainability' is probably ignored by the agents in LRFF networks, especially the marketing networks, because it is understood to be an inhibiting factor that denies room to manoeuvre by punggawas darat and boses in their quest to maximise their incomes. In this paper, the term 'room to manoeuvre' relates to opportunities for agents to maximise income by establishing other income generating activities, which might be done by extending the social networks, especially to people in the government sector or the private sector. One of the boses has been identified as developing his room to manoeuvre by supporting important political figures in South Sulawesi and by so doing extending his networks, which has enabled him to expand his business enterprises and move into activities related to building and construction. One of the punggawas darat has increased his room to manoeuvre by expanding his business enterprises to property-related activities in Makassar. This paper argues that these horizontal entrepreneurial shifts to other business activities are to ensure that income does not fall away over time. This suggests that efforts to ensure the sustainability of LRFF fishery are being undermined by the belief, assumption or understanding that reef fishery cannot be relied on to generate sufficient income in the long term.

There have been various research projects focusing on LRFF fishing and trade that support efforts to promote sustainability in reef fishery but a few only have focused on understanding the underlying social networks. Our research shows that understanding these social networks 
are important for ensuring its sustainability. Findings on prosecution insurance networks in reef fishery have been reported as well by different researchers (Meereboer, 1997; Erdmann, 2001; Lowe, 2000); however, little attention has been given to the importance of social networks in LRFF fishing and trade. These social networks are dynamic and involve many people over various islands of the Spermonde Archipelago. This paper only focuses on the model that represents the static type of connections in social networks of reef fishery and does not take into account their dynamics. However, findings from our research are important; they demonstrate the importance of shifting the debate away from blaming the local communities only for their destructive fishing practices as being the cause of unsustainability in reef fishery. Investigating the social networks and their components gives the bigger picture of the whole reef fishery system and takes the market and jural regimes into account, which are necessary for promoting the sustainable fisheries by taking diversified approaches instead of single, top-down conservation and development approaches.

This research offers a new perspective in examining sustainability by understanding and examining the social networks. By examining social networks it is possible to identify different interactions among agents that characterise various interests. In the reef fishery case, it is identified that the social networks attached to the resources (fishing networks) are more characterised by socioeconomic interests, where self-esteem and social prestige are present and influential. On the other hand, the social networks attached to fish marketing are more characterised by profit maximisation, and the social networks attached to the policy and administrative aspect are characterised by maximising additional income through corruption. The interplay of socioeconomic interests, profit maximisation and maximising additional income have been the foundation of the LRFF fishing and trade. It gives new insights on how to promote sustainability in fisheries better through understanding the diversity of social networks. 
Further research needs to be carried out to elaborate more the dynamics of such social networks, which are important for supporting any attempt to promote sustainability in fisheries. We would like to encourage more work on the effects of corruption on sustainability, which arguably is still untouched and left out from research agendas despite of its importance. Additionally we would like to encourage as well research that employs different measures in network analysis, for example, centrality and betweenness measure in the context of sustainability. The results discussed in this paper would be a good baseline for such research.

\section{Acknowledgement}

The author would like to thank Dr Habil Marion Glaser and Prof Dr Michael Flitner, Dr Verania Andria, Rio Deswandi, Muhammad Neil and Sainab Husain for their very insightful and valuable discussion and support; and also Rinto Andhi Suncoko, Muhammad Hafes Assaad, Umar, Yuli, Sunarto, Gunardi, Keyka, and Edhy Perdana for their valuable support in collecting data. Credits also go to the punggawas darat and fishermen from the islands of Karanrang, Sarappo Lompo, Bone Tambung, Badi, Barrang Caddi and Barrang Lompo. The author also would like to thank the Leibniz Center for Tropical Marine Ecology in Bremen for its financial support for the research under the Science for the Protection of Indonesian Marine and Coastal Ecosystem (SPICE) program.

\section{Bibliography}

Adger, WN, K Brown and EL Tompkins. (2006). 'The political economy of crossscale networks in resource co-management'. Ecology and society, 10(2): 9.

Baitoningsih, W. (2009). Community participation in designing Marine Protected Area in Spermonde Archipelago, South Sulawesi, Indonesia. (Master thesis). Bremen: University of Bremen.

Barabási, A-L. (2009). 'Scale-free networks: a decade and beyond'. Science, 325(5939): 412-13. 
Barber CV and VR Pratt. (1997). Sullied seas: strategies for combating cyanide fishing in Southeast Asia and beyond. Washington: World Resources Institute and International Marinelife Alliance.

Bentley, N. (1999). Fishing for solutions: can the live trade in wild groupers and wrasse from Southeast Asia be managed? Kuala Lumpur: TRAFFIC Southeast Asia.

Bodin, Ö, B Crona and H Ernstson. (2006). 'Social networks in natural resource management: what is there to learn from a structural perspective? , Ecology and society, 11(2): $\mathrm{r} 2$.

Bohman, T. (2009). 'Emergence of connectivity in networks'. Science, 323(5920): $1438-39$.

Borgatti, SP, A Mehra, DJ Brass and G Labianca. (2009). 'Network analysis in the social sciences'. Science, 323(5916): 892-95.

Brugnach, M, A Dewulf, C Pahl-Wostl and T Taillie. (2008). 'Toward a relational concept of uncertainty: about knowing too little, knowing too differently, and accepting not to know'. Ecology and society, 13(2): 30.

Crona, B., M Nyström, C Folke and N Jiddawi. (2010). 'Middlemen, a critical socialecological link in coastal communities of Kenya and Zanzibar'. Marine policy, 34: 761-71.

Chozin, M. (2008). Illegal but common: life of blast fishermen in the Spermonde Archipelago, South Sulawesi, Indonesia. (Master thesis). Ohio University, Athens.

Deswandi, R. (in preparation). 'Understanding institutional dynamic of capture fisheries in Makassar, South Sulawesi, Indonesia'. (PhD thesis to be submitted to the Faculty of Social Sciences). University of Bremen, Bremen.

Erdmann M. (2001). 'Who's minding the reef? Corruption and enforcement in Indonesia'. SPC Live Reef Fish Information Bulletin, 8: 19-20.

Fabinyi, M and D Dalabajan. (2011). 'Policy and practice in the live reef fish for food trade: a case study from Palawan, Philippines'. Marine policy, 35: 371-78

Fausi, A. (2005). Kebijakan perikanan dan kelautan. Jakarta: Gramedia Pustaka Utama.

Fougères, D. (2005). Aquarian capitalism and transition in Indonesia. (PhD dissertation). University of California, Berkeley.

Fougères , D. (2008). 'Old markets, new commodities: aquarian capitalism in Indonesia'. In J Nevins and NL Peluso (eds). Taking Southeast Asia to market: commodities, nature and people in the neoliberal age Ithaca: Cornell University Press.

Glaser, M, W Baitoningsih, SCA Ferse, M Neil and R Deswandi. (2010). 'Whose sustainability? Top-down participation and emergent rules in marine protected area management in Indonesia'. Marine policy, 34: 1215-25.

Glaser, M, I Radjawali, SCA Ferse and B Glaeser. (2010). 'Nested participation in hierarchical societies? Lessons for social-ecological research and management'. International journal of society systems science, 2(4): 390-414. 
Johannes, RE and M Riepen. (1995). Environmental, economic, and social implications of the live reef fish trade in Asia and the Western Pacific. Bonnet Hill: R.E. Johannes Pty Ltd.

Johnston, B and B Yeeting (eds). (2006). Economics and marketing of the live reef fish trade in Asia-Pacific. Canberra: Australian Centre for International Agricultural Research. (ACIAR working paper 60)

Johnston, B (ed.). (2007). Economics and market analysis of the live reef-fish trade in the Asia-Pacific region. Canberra: Australian Centre for International Agricultural Research. (ACIAR working paper 63)

Lau, PPF and R Parry-Jones. (1999). The Hong Kong trade in live reef fish for food. Hong Kong: TRAFFIC East Asia.

Lauber, TB, DJ Decker and BA Knuth. (2008). 'Social networks and communitybased natural resource management'. Environmental management, 42(4): $677-87$.

Lowe, C. (2000). 'Global markets, local injustice in Southeast Asian Seas: the live fish trade and local fishers in the Togean Islands of Sulawesi'. In C Zerner (ed.). People, plants and justice: the politics of nature conservation. New York: Columbia University Press.

Mánez, KS and SCA Ferse. (2010). 'The history of Makassan trepang fishing and trade', PLoS ONE 5(6): e11346.

Marin, A and F Berkes. (2010). 'Network approach for understanding small-scale fisheries governance: the case of the Chilean coastal co-management system', Marine Policy 34: 851-58.

Meereboer, M-T. (1998). 'Fishing for credit: patronage and debt relations in the Spermonde Archipelago, Indonesia'. In K Robinson and M Paeni (eds). Living through histories. Culture, history and social life in South-Sulawesi. Canberra: Australian National University Press.

Mous, PJ, L Pet-Soede, M Erdmann, HSJ Cesar, Y Sadovy and JS Pet. (2000). 'Cyanide fishing on Indonesian coral reefs for the live food fish market - What is the problem?' In HSJ Cesar (ed.). Collected essays on the economics of coral reefs. Kalmar: CORDIO.

Norberg, Jon and GS Cumming (eds.). (2008). Complexity theory for a sustainable future. New York: Columbia University Press.

PAN-UK. (2001). 'Rotenone'. Pesticides news, 54: 20-21. Accessible from http:// www.pan-uk.org/pestnews/Actives/rotenone.htm.

Pelras, C. (2000). 'Patron-client ties among the Bugis and Makassarese of South Sulawesi'. Bijdragen tot de Taal-, Land-en Volkenkunde, 156(3): 393-432.

Pet-Soede, L and M Erdmann. (1998). 'An overview and comparison of destructive fishing practices in Indonesia'. SPC live reef fish information bulletin, 4.

Putra, HSA. (1988). Minawang: hubungan patron-klien di Sulawesi Selatan. Yogyakarta: Gadjah Mada University Press.

Radjawali, I. (2010). 'Reconsidering development-coping with uncertainties: live reef food fish (LRFF) trade in Spermonde Archipelago, Indonesia'. 


\section{ARTICLES}

Reconsidering development, 3(1). Accessible from http://journal.ipid-umn.org/ $\underline{\text { node } / 87}$

Sandström, AC and CV Rova. (2010). 'The network structure of adaptive governance: a single case study of a fish management area'. International journal of the commons, 4(1): 528-551

Satria, A. (2009. Pesisir dan laut untuk rakyat. Bogor: IPB Press. 